\title{
Shari'ah Implementation in a Democratic Nigeria: Historical Background and the Quest for Developmental Legality
}

\author{
Dr. Juwayriya Badamasiuy \\ Faculty of Law, Bayero University, Kano \\ PMB 3011, Kano, Nigeria \\ Tel: 234-805-841-9706Ｅ-mail: juwabadamasi@yahoo.co.uk
}

\author{
Dr. Ahmed Adam Okene \\ Visiting Scholar \\ Universiti Utara Malaysia College of Arts \& Sciences \\ 06010 Sintok, Kedah, Darul Aman, Malaysia
}

Tel: 60-13-397-1431_E-mail: ahmedokene2001@yahoo.com/ahmadokene@uum.edu.my

Received: April 6, $2011 \quad$ Accepted: April 26, $2011 \quad$ doi:10.5539/jpl.v4n2p144

\begin{abstract}
The return of democracy in Nigeria’s political landscape in 1999 after decades of either brutal military dictatorship or truncated democracy brought several opportunities to citizens. Democracy to Northern Nigeria Muslims meant an avenue to return to the full application of Shari'ah Islamic law through the purview of operational 1999 constitution. However, the manners of the implementation of sharia'h in an environment of pervasive official sleazebag, infrastructural decay and lack of transparency created inertia, despondency and mistrust. If sharia' $h$ is to have fruitful meanings, it has to be developmental. This work discusses all these, the history and the controversies that surrounds the application of shari'ah and insisted that sharia' $h$ states of Nigeria should concentrate on the aspects that foster prosperity, good governance, equity in ownership and distribution of wealth while also exploring developmental micro- takaful and awkaf so as to improve the well beings of the poor.
\end{abstract}

Keywords: Plurality, Implementation, Awkaf, Takaful, Shari’ah, Legitimacy, Empowerment, Democratization.

\section{Introduction}

Democracy became exceptionally important issues after the cessation of the cold war and the emergence of the United States of America as the dominant power in the global scene. Since then, the developing economies became more relevant in the political chess game of, and among, the contending powers. More than ever, Democracy as a perceived universal political values became a rallying tool for alliances and socio- cultural and diplomatic relationship. So intense is the imbuement of the spirit of democracy and indeed democratization that in the early $21^{\text {st }}$ Century, the Middle East, particularly the Arab world is currently saturated with the demands most of which are violent for the institution of democracy and representative governance in their countries. In February 2011, both Mr. Ben Ali and Mr. Hosni Mubarak erstwhile powerful dictators of Tunisia and Egypt respectively were deposed by the popular peoples' revolutions. And at the close of March 2011, the United Nation Supreme Council (UNSC) has imposed no-fly area on the Libya Government and has even gone ahead to authorize the use of force to stop Col. Muammar Gaddafi, Libya's leader from massacring the people behind pro-democracy uprising in that country.

Nigeria, the most populous black African nation has suffered under undemocratic regimes and opportunistic misrule for three decades and a half after independence in 1960. The British colonial rule in Nigeria which spanned 1861 and 1960 and the legacy of that ruler ship sowed the seed of crises, domestic contradictions and general conflicts in all ramifications. In this vein, the exploitation of the existing ethnic and other identity based groups, as indeed the apparent differences of Islam and Christianity, the two dominant religions, and the apparent religionization of democracy in the country, have become contentious issues posing serious challenges to the political, leadership and indeed, corporate existence of Nigeria in the $21^{\text {st }}$ century. Islam as a civilization and worldview predates modern Nigeria. It was established as a state religion in a larger environment that comprised almost all the parts of Northern Nigeria and beyond. As such therefore, Islamic law technically called the Shar'iah served all sectors, functionalities and structures before the British occupation 
The struggle to revitalize Islam especially its legal aspect is historical dating from the day the British set its foot on Northern Nigeria in 1885 when its agent, the National African Company forced Bula, the chief of Ibi in Niger- Benue territory, north east Nigeria to sign a treaty surrounding his lands (Abubakar, 1899). Having occupied the Nigerian areas, the British established itself as the new ruler with change in policy and direction of the society so much so that Islamic religion and law not only cease to be state religion and the legal system of the Northern Nigeria but its application became dependent on the law introduced by the British. However, with the re entrance of democracy in Nigeria in 1999, Islam's legal system has now found an established footing in an otherwise westernized and secularized national legal system to flourish. So serious is this marriage in the current dispensation that the use of democracy and the provisions of the Federal Constitution are being reinterpreted to accommodate the operation of the Shari'ah.

\subsection{Conceptual Clarification}

Before we go into deeper exposition of the subject matter, there is the need to define and clarify some of the major terms and concepts used, so as to make the discussion fully comprehensive within its conceptual framework.

\subsubsection{The Shari'ah}

Shari'ah is a complete way of life encompassing all aspects of human life; the religious, social, legal, economic, political and intellectual spheres. The Shari'ah upholds justice, fairness and tolerance and therefore application of its legal aspect to Muslim social life is considered mandatory. Thus, the administration of justice is always regarded as one of the most important functions of any Muslim government. It is incumbent upon the leadership of the Muslim Community, according to the Shari'ah, to establish and maintain justice among the members of the society (Ladan, 2003:21)

The Shari'ah according to the Muslim are sets of law ordained by Allah (Almighty God), the Creator in the Qur'an and as practiced through the traditions, sayings and actions of Prophet Muhammad (Peace be upon him). The law also contains the interpretations and expositions of the Prophet's companions and renowned Islamic scholars of all ages. Though the laws themselves to the Muslims are divine and immutable, interpretations, meanings and understanding differ depending on period, environment and circumstances. In the same vein, human rights under the Shari' ah means that the citizen's freedom of movement, expression, religion and other forms of development are not unnecessarily disturbed except in accordance to the due process of law. In Shari'ah, sovereignty belongs to Allah, since He is the Creator, Nourisher and Sustainer of the universe (Maududi, 1975).

\subsubsection{Democracy}

Democracy, on the other hand, construes man as the centerpiece and focal point of its body of operation. This is why sovereignty belongs to him just as supreme power is vested in the people collectively and is administered by them or by officers appointed by them. However, in a general sense democracy is governed by multipartism, electoral competition, respect for fundamental human rights and equality before the law. Political theorists have often divided democracy into four components; contestation over policy and political competition for office; the participation of the citizenry through partisan but collective actions; accountability of the rulers to the electorates through the mechanism of representation, plurality and the rule of law and, finally, civilian control over the military. The level of democracy in a country, concisely, is determined by the extent to which the country regularly holds free, fair and competitive elections, has fair electoral laws, and endows elected officials with real power.

\subsubsection{Democratization}

On its own, democratization is the process of attaining democracy. Since it presupposes the non-existence of democracy, a process is created that invest power with legitimacy, facilitates the creation of enduring political institutions, and nurtures responsive political pluralism. It also involves the promotion and defense of personal liberties, social justice and fundamental human rights. As a process and transit therefore, democratization involves the operation and institutionalization of democratic principles, values and structures at a period when "confrontations tend to focus on the nature of the political institutions to be established, the advantage that should be given to interested parties and the set-up and re-distribution of public resources" (O'Donnell and Schmitter, 1987). Democratization is often accompanied with liberalization. Liberalization has been defined by Johnston and Lee (2003) as the political opening of a country, which broadly includes the freedom of expression and belief, association and organizational rights, rule of law and fundamental human rights, and personal liberty and economic rights.

Democratization in Nigeria commenced during British colonial rule, especially after the Second World War, when colonial authoritarianism was deliberately relaxed to give way to some airs of freedom in expression, association, religion and partisan politicking. In this vein therefore, the 1946 Sir Arthur Richards Constitution allowed the formation of political associations, created both Federal and Regional Houses of Representatives, permitted the 
conduct of elections and created atmosphere of general political liberalization. Though, the British claimed that the Richards constitution was designed to "promote the unity of Nigeria, to provide adequately within that unity for the diverse elements which make up the country, and to secure greater participation by Africans of their own" (GBCO 1945), it was nevertheless criticized by the Nationalists like Nnamidi Azikwe and Raji Abdallah of among many others, as an imposition from the top (Olusanya, 1999). Whatever the case, though autocratic and exploitative, the British Colonial Government laid the foundation for constitutional making in Nigeria.

In the post-colonial period until 1999, democratization was characterized by a series of political transitions and toleration of some basic human rights designed and implemented by despotic military regimes. Scholars are still arguing whether the experience so far from 1999 to date is full democracy or mere transition to civil rule. For example, Bako (2002) observes that Nigeria has been embroiled in more time - wasting, expensive and flamboyant and highly militarized state-guarded and exclusive transitions than in real sustainable democracy, Oyovbaire Samuel a scholar of political administration in Third World in his unpublished Memorandum, "A Reflection of the Current Transition to Civil Rule" to a learned conference on Democracy in Lagos, Nigeria in 2001 viewed the entrance of the fourth republic from 1999 as chaotic, unmediated by rationality and purposefulness. On his own, Attahiru Jega a professor of Political Science and currently the Nigeria's Elections Chief, in his paper, "Towards Sustainable Democracy in Nigeria” delivered to members of the Kano State House of Assembly in June 2000, decried the confounding, disappointing and disconcerting, very sad and sorry state of our collective quest and struggles for democracy.

\subsubsection{Good Governance}

Good governance is simply defined as the responsible use of political authority to manage a nation's affairs. Good governance is closely related to the provision of public goods, accountability and transparency. As such good governance is descriptive of a professional civil service, the supremacy of the rule of law, the effective protection of human rights, a diminution of corruption in government, a predictable and transparent administration, democratic decision making, a fair and egalitarian economic order and the appropriate devolution and decentralization of government. The United Nations Development Programme in its 1997 policy document examined the essential characteristics of good governance to include participation, transparency, accountability, effectiveness, equitability, and indeed the promotion of the rule of law.

However, from Shari'ah epistemology, good governance involves three essential elements; justice, consultation and equality before the law. While justice in this vein is all encompassing from the social through the administrative and economic realms, the Shari'ah arranges the relationship between the government and the governed community and regulates the authority of the government in relation to the freedom of the subjects. The Shari'ah system being a constitutional system that reserves sovereignty to $t$ he Almighty Creator, vests government authority not on any individual monarch and autocrat, but on the community through their representatives, and insists that consultation and consensus decisions should be maintained as the basis of good governance (Badamasiuy, 2011).

Unfortunately, since independence in 1960, bad civilian and military leaders who unleashed regimes of autocratic and authoritarian misrule on the citizenry have ruled Nigeria. The collective hope, which heralded the fourth republic in 1999, was dashed by the foisting of a presidential monarchy under President Olusegun Obasanjo (1999-2007). Thus, instead of presidential democracy, what Nigerians got since 1999 was an entrenched political and financial corruption, which, to Joseph (2003), has become one element of a broader phenomenon that can be called "catastrophic governance”. 'Catastrophic governance' is the endemic practice that steadily undermines a country's capacity to increase the supply of public goods. A decade plus into the fourth republic, Nigeria's democracy is still unrepresentative and unaccountable, as it reels from one of the worst scenario of corruption in a developing economy.

\section{A Historical Account of the Demand for the Shari'ah in Nigeria}

Islam in Nigeria dates back to the $8^{\text {th }}$ century. However, the actual establishment of Islam as a spiritual creed and as state policy should be traced to the jihad of Shehu Usman Danfodio (1754-1817) in 1804. As a profound religio-political revolution, the Sokoto Jihad led to the creation of a geo-political entity called the Sokoto Caliphate encompassing at least two thirds of the modern Nigeria, a substantial part of the southern Niger Republic and Ngaudere and Tibati in the Republic of Cameroon (Smith, 1987; Suleiman, 1986). The Caliphate also had institutional extension to Segon and Masina in the Republic of Mali, Fouta Djallon in the Republic of Guinea, Fouta Toro in Sene-Gambia area, Northern Ghana, Chad in the Central Africa and further east in the Republic of Sudasn (Okene and Shukri, 2011) The Jihad engendered the administration of Shari'ah justice in governance, politics, law, socio-economic and diplomatic relations and intellectual spheres. Autonomous administrative units, known as the emirates (about thirty of such were created all over the central Bilad al — Sudan (appropriately modern West Africa) in a total area of some 250,000 square miles), used Shari'ah Islamic law in one form or the other to administer justice and governed the faithful and other groups (Mahmud, 1988). But by the third quarter of the $19^{\text {th }}$ century, the ideals and 
values of the Jihad had been compromised and corrupted, as the leaders of the caliphate reverted to the pre-jihad socio-political evils of the Sudanese states, which, in the first case, necessitated the Jihad (Okene and Shukri, 2011). The violent occupation of the Nigerian region by the British Imperial forces commencing from the $19^{\text {th }}$ century and culminating in the establishment of the colonial state in Nigeria brought a set of rules alien to the people and systematically obliterated the Shari'ah administration (Abubakar, 1999; Yadudu, 2003; Kumo, 1986).

The British meticulously abrogated the socio-political and economic structure and super structure of the country. However, the greatest impact of British rule on the Muslim emirates was the impingement of the Shari'ah legal system and the consignment of the system to courts of some personal laws (Section 2421979 constitution \& sections 244[1] \&277[1] 1999 constitution of Nigeria. The systematic slow but calculated policy of replacing the Islamic law with English law started with the prohibition of judge applying Islamic law from imposing "inhuman treatment" (Proclamation No 5 of 1900 \& 1906). This is supported with the treatment of Islamic law as specie of Native Law and Custom and subjecting it to repugnancy and incompatibility tests (section 34[1] High Court Laws, Adesubokun v Yunusa). Then the introduction of the Penal Code in 1959 borrowed from Sudan and India to ouster the remain of the Islamic criminal justice or at least to render Islamic law to be subservient to the English penal system. As long as the British held sway with its complex despotic administrative style, religious agitation, especially the Muslim demand for wholesome application of the Shari'ah, was peripheral.

However, on its way out, the British had in 1956 incorporated a single Shari'ah court of Appeal for the Northern region. This court was operated in the first Republic (1960-65). In 1976, the Rotimi Williams-led Constitution Drafting Committee (CDC) proposed the establishment of Shari'ah Courts of Appeal at state and federal levels. The tension generated during the proceedings of the 1977/78 Constituent Assembly (CA) resulted in the stalemate and walkout by Muslims in protest against the manner the issue was handled. Nevertheless, the Supreme Military Council (SMC), the highest ruling body of the military regime, then arrived at a compromise by retaining the provision for the establishment of the Shari'ah court for any state, which required it. It also created an Islamic Law division, (more appropriately "the bench"), in both the Court of Appeal and the Supreme Court (Yadudu, 1991). However, the most intense religious stalemate over Shari'ah application was witnessed in the Constituent Assembly of 1988/89. The Christian politicians and elite who dominated the Assembly used their preponderance to call not only for the total abrogation of Shari'ah law in the constitution but particularly the erosion of any word "Shari' ah Court" from the draft Constitution. This created a social tension and a situation near political conflagration in an environment that was already saturated with matters of official corruption and military debauchery. As usual of its mediating role, the Armed Forces Ruling Council (AFRC) intervened by making issues of Shari'ah non-debatable in the Assembly. The 1989 promulgated draft Constitution adopted the recommendation of the Constituent Assembly.

Although the Constitutional Conference of 1994/95 was not bedeviled by serious acrimonious debate over the Shari'ah, the 1998 Constitutional Debate Co-ordination Committee recommendation for the retention of the provisions of the 1995 draft Constitution became smeared in severe controversy. The South West media outfits under some religious influences discredited the then Head of State, General Sani Abacha, by spreading false rumor that there was disagreement at the highest decision making body of the ruling military brass over what should be the position of the Shari'ah in the constitution (Yadudu, 1999).

Ultimately, the post Abacha's era civil governance is anchored on this Constitution based on the 1999 constitution. Though the Abacha's regime (1993-1998) had ensured relative economic stability, the regime's flagrant violation of human rights created disaffection and suspicion all over the country. More so, his successor, General Abubakar Abdulsalami, had successfully handed over to democratically elected leaders. This last military contraption, like most military regimes of third world, was intellectually bankrupt and economically inept. Unfortunately, the coming of Olusegun Obasanjo in a democratic system has not helped matters. Infrastructures have continued to visibly decay. Unemployment had dramatically risen up; ethnic-political violence and religious conflagration were rampant than hitherto. Hunger, diseases and illiteracy due to poor economic environment and the exorbitant cost of education led to increase the socio- economic tension and polarization of various social forces in the country. Nigerians became skeptical as to whether the immediate post military civilian government can galvanize the country to decisive democratic dividends. There were certainly widespread corruption in the Executive and Legislative House (the famous Chief Wabara-Osuji and Mobolaji Osomo's scandal of March April 2005), wanton insecurity in which high profile Minister like Bola Ige and an elderstateman like Harry Marshal were unaccountably murdered in December 2005 and March 2003 respectively. In addition, there were youth restiveness all over the country especially in the Niger Delta region and excessive inclination towards exploitative western capitalistic systems (Okene, 2005; Daily Sun, March 2005, 23:4). All these created suspicions among the citizenry. The Muslims in particular feel that the only viable option to corrupt leadership and exploitative environment was to earnestly return to path of Shari'ah and implement its contents holistically. 


\subsection{Shari'ah Implementation in a Democratic Zamfara State}

On October 27, 1999, Zamfara state in the North Western part of Nigeria heralded the implementation of "total Shari'ah" (Islamic Law) through a highly publicized and well celebrated launching to the glare of a crowd of well over a million people. The Shari'ah launching, which drew representatives from both neighboring countries like Chad, Niger, Sudan and Egypt and far away countries like Saudi Arabia, Iran and Pakistan, generated heated controversies within the country just as it invited the curious interest and concerned attention of the international communities.

The new initiative with Zamfara taking the lead expectedly had impact on other Muslim dominated states of Northern Nigeria and indeed Western states of the country, as most of them, including Kano, the commercial nerve centre of the North, Kebbi, Sokoto, Borno, Niger, and Yobe, joined the group of Shari'ah states.

Ahmed Sani, the Governor of Zamfara State, stated his confidence in the Constitution of the Federal republic of Nigeria and took a firm commitment that Zamfara state "will ensure the security of lives and properties of all people residing in the state irrespective of their religion or tribe and will ensure justice and fairness to all" (Weekly Trust, Nov. 12, 1999). However, for the first time after the fall of the Nigerian nation to the Imperial British in the first decade of the $20^{\text {th }}$ century, there is the official sponsorship of Islam in politics and governance. By the introduction and indeed implementation of the criminal aspect of the Islamic Law, the plurality of the nation once again was provoked and put to test. Understandably, ignorance and apparent mischief were displayed. Infact, a section of the country brandished cessation card. There was the upsurge of religio-centrism leading to violence and arson in Kaduna in February and May 2000. Kaduna is the administrative centre and political hobnob of Northern Nigeria and the seat of some of its elites known for their religio-political manipulation. In every sense, Nigeria is a country of divide and dysfunctional pluralism: Islam versus Christianity; the North versus the South; the rich versus the poor and the elite versus the masses. All these divisions are usually brought to harp on the socio-political contestations in the country

Critical debates and discourses were resorted to in the public fora. Spurious and highly provoking editorials and feature articles were printed in the daily newspapers and the weekly news magazines. The application of the Shari'ah by some Northern states has simply revived the debate on the application of it in a democratic Nigeria. The newfound democracy coupled with the religious and political significance of the issue has jointly given the issue its traditional explosive prominence. The Christian elite and the Southern Nigeria media outfits wrote to condemn the Shari'ah, and its application in some states of the country, believing that it was being introduced to truncate democracy and divide the Nigerian people (Tell Nov. 15, 1999).

Conversely, the Northern Nigeria media and the regions' elite and indeed enlightened Muslims of Southern Nigeria origin supported the Shari'ah and all efforts to ensure its full implementation. They felt that Muslims were protected by the operational constitution to implement Shari'ah and just as they have fundamental human rights to practice their faith. This was the view expressed by the Secretary General of the Nigeria's Supreme Council for Islamic Affairs, Abdullateef Adegbite in the position paper, "Position of Muslims on the Restructuring of Federation: What Case for the Application of Shari'ah" he presented at the National Conference on the Application of Shari'ah in a Democratic Nigeria, Bayero University, Kano in December 1999.

\subsection{The Constitutional Provisions and Democratic Procedures for Introducing the Shari'ah}

With the new tolerant political environment heralded by the re-introduction of democracy in May 1999, a new dimension was given to the issue of the Shari'ah. Ahmed Sani of Zamfara leading other states' governors explored the various provisions of the enabling 1999 Nigerian Constitution to introduce the Shari'ah in his state. Apparently the Governor had made the introduction of the Islamic criminal law as part of his campaign manifesto. He relied on the provisions of sections 4(7), 6(4) \& (5), 38, 277-278 as relevant schedules. Section 38(1) of the 1999 constitution of the Federal Republic of Nigeria, for instance, states that "Every person shall be entitled to freedom of thought, conscience and religion, including freedom to change his religious belief, and freedom (either alone or in community with others, and in public or private) to manifest and propagate his religion or belief in worship, teaching, practice and observation." The Governor approved the bill establishing the Shari'ah penal code passed by the Zamfara House of Assembly in January 2000, emphasizing the fact that his State has not contravened the constitutional provision forbidding state religion. Sani and Muslim scholars insisted that if Zamfara State were to adopt Islam as a State religion, there would not have been magistrate courts or high courts and even churches in the State. What the State did was to have two legal systems; Shari'ah Courts to administer Shari'ah Laws for Muslims and Conventional Courts (Magistrate and High Courts) to Administer Common Law for non-Muslims (Yadudu, 2003).

\subsection{Opposition against the Shari'ah}

To the bulk of suspecting non-Muslims in the country, especially Christians, the introduction of the criminal aspect of Islamic Law by Zamfara and indeed any State in Nigeria was provocative. According to them, doing this would mean 
having two constitutions in a common geo-polity. Ben Nwabueze a former Nigerian Minister of Justice used the instrumentality of the Constitution to oppose the adoption of the Shari'ah legal system. Nwabueze insists that the practice of the Shari'ah and the observance of the moral precepts and injunctions in the Qur'an are a personal matter for the individuals to be inculcated by teaching and preaching in the Quranic Schools and Mosques, by individual self-abnegation and self-discipline, not by enforcement through the coercive machinery of government belonging to Muslims and non-Muslims alike. Giving legal and intellectual backing to the anti-Shari'ah position, Nwabueze writes that the Shari'ah Law adopted by Zamfara State is inconsistent with some provisions in the fundamental rights Chapter (chapter IV) of the 1999 constitution. He observes that the Shari'ah law of the Shari'ah states does not satisfy section 36(12), which provides that a person shall not be convicted of a criminal offence unless that offence is defined and the penalty prescribed in the written Law in form of an act of the National Assembly or Law of a state (The Post Express $13^{\text {th }}$ April, 2001).

To the protagonists of the Shari'ah legal system in Nigeria, Nwabueze's treatise argued only the usual intellectual stereotype of the anti-Shari'ah sentiments. To them, the treatise failed to explore and juxtapose the various constitutional clauses and provisions to see the historic-psychology of Muslims and their legal system, which predated the existence of Nigeria as a nation state. Islam to the pro-Shari'ah is a comprehensive civilization and worldview, which is both metahistorical and international. It transcends time and space and embraces all kinds of peoples, languages and culture in the world (Muazam, 2002; Okene, 2005).

Accordingly, since the Nigerian federation is predicated on the principles of democracy and social justice, which uphold the equality of rights, obligations and opportunities before the law, it presupposes that such principles prohibit discrimination on the same grounds, which inter alia include religion. As such, to disallow Muslims from implementation of their religious requirements is against the intent of democracy in Nigeria, since the 1999 Constitution demands from the Government at whatever level to exercise such power that will achieve public order, safety, peace and accountable government. The provision of all these and more is the basic objective of the Shari'ah, which has become a written and codified law for over a thousand and four hundred years.

According to Justice M. A. Oredola in his unpublished paper, "The Constitution and the New Initiative" presented to a conference on the Application of Shari'ah in a Democratic Nigeria at Bayero University, Kano in December 1999, the Shari'ah initiative pioneered by Zamfara state government duly satisfied the relevant provisions of the Nigerian Constitution. A senior judge himself, Oredola contends that for Zamfara state to have given three months notice before the commencement of the law meant that it was conscious of fulfilling section 36(8) of the 1999 Constitution, which provides that there should not be retrospective criminal laws. He argues further that section 6(4) (a) of the same Constitution empowers both the National Assembly or State House of Assembly to establish or create and abolish courts in as much as such courts do not encroach on the items of the Exclusive Legislative List as enunciated in the Second Schedule part 1 of section 4(1) and (2) of the Constitution.

Interestingly, the Federal Government after unsuccessful moves to prevent other Muslim Governors, especially of the Northern States, from applying Islamic Laws, attempted to use blackmail and federal might to quash the desire. For instance, the Nigeria Air Force in Kaduna prevented Muslim crowd from traveling to Kano during the state launching of the Shari'ah on the $21^{\text {st }}$ of June 2000. Eventually, the Shari'ah case was referred to the Federal Ministry of Justice under Chief Kanu Agabi, a Christian and legal luminary, which ruled in favour of the legality of the Law in Muslim dominated states and on Muslims alone. It is worthy to mention here that apart from Governor Ahmed Sani of Zamfara, all other Governors of the Shari'ah States introduced the legal system as a result of the pressure by the electorates. Again, the 2003 political campaigns were anchored on the promise by various contestants at various political units and levels in the Muslim dominated areas, especially in northern Nigeria that they shall implement the Shari'ah Law. It is instructive to note that Mr Ibrahim Shekarau won election in 2003 and 2007 as Governor of Kano State largely on this platform.

\section{The Need for Developmental Legality}

Since democracy is about the choice of good governance, it should be rearranged in such a way as to allow people to live by the dictates of their chosen beliefs, norms and values within a corporate federal nation state. There is the need therefore that a common ground should be found for the Shari'ah states to ensure constructive development and prosperity. The Shari'ah and democracy may be far apart ideologically and historic-contextually. The upholding of democracy of some positive values that are pristine and sacrosanct to Islam and its law, the Shari'ah show that Shari'ah rule could fostered in some setting of democracy. Democratic values like economic development, good governance, transparency, accountability, fair play, and indeed the tolerance of opposition and differing views are norms and values of the Shari'ah. Where applicable, with the current impoverished state of Nigeria, the implementation of the Shari'ah should uphold true Islam, which is pristinely developmental. This emphasizes the 
improvement of welfare through the advancement, re-organization and re-orientation of the entire economic and social systems as enshrined within the body of Shari'ah. Material culture should grow pari passu with the social culture. There should be a deliberate effort to capitalize on the link between religion which emphasizes accountability, service to humanity and political transparency, on the one hand, and developmental aspect of democracy.

The Shari'ah states needs to be systematic in their application of the law. Phases of transformation should be delineated and worked out in such a way that they take care of quality and society oriented and focused education; creation of employment; women empowerment; health and infrastructural provision. Shari'ah law legitimizing all these should be properly codified. Dialogue as a link between development and democracy should be preached while degradation and suffering, such as hunger, disease, illiteracy, exploitation, sheer drudgery, repression and anachronistic domination, which are condemned by the Shari'ah, and are fertile avenues for religious violence, cleavages and war, should be avoided. Nigeria's democracy should truly uphold ethnic and religious pluralities as platform for progress and development.

It should be pointed out here that in pursuing the good governance aspect of the Shari'ah, the Shari'ah states of democratic Nigeria should be particularly concerned with improving the socio-economic well being and qualities of life of the weak, and the vulnerable groups. This is because they are the most indispensable but acutely susceptible to abuse and easily exploited groups in the socio-economic strata of the society. More so, Shari'ah has particularly given attention to their well being and has caution administrators of trampling on their rights and welfare. They should therefore, as a matter of obligation be exposed to the knowledge of their trades from both religious and societal requirements. These groups, which include farmers, black-smiths, carpenters, tailors, dyers, grocers, butchers and commercial Motorcycle operators (i.e. Okada in Nigeria parlance), should be provided with amenities that will enhance their maximum productivity and thereby ginger growth in the political economy of the state.

Also the laws guiding family life, acquisition and transfer of land, trading and commercial activities should be promulgated and regulated within the context of the Shari'ah so as to encourage family cohesion, inter cultural harmony, economic integration and maximum production output. It is also hoped that such rules will protect family from disintegration, the individual and the social system from political crime, fraud and financial corruption, which have become an embarrassing nightmare in the current democratic dispensation.

The leadership must create an enabling environment to ensure equity in the ownership of the means of production and ensure an equitable wealth distribution system. This therefore calls for the re-appraisal of the on-going privatization exercise, which is increasingly subjecting the teeming populace of Nigeria to misery. Without a solid capital base and successful industrialization, privatization has so far only boosted the influence of powerful vested interests, individual forces and multi-nationals. Islamic financial institutions should be utilized in poverty alleviation. The micro financial bodies and institutions such as micro takaful- Islamic insurance, micro Islamic banking and awkaf which even the financial capitals of the West are now exploring should be organized, embarked upon and baked by law to solve acute fund problems of the poor. All these financial funding devices should be viewed within Small and Medium Enterprises (SMEs).

For the Shari'ah states, the challenges are daunting. The momentum which is steadily been lost because of the initial disappointment from the implementers should be revived. Though the trend in the states is the application of capital punishment on stealing and extra-marital relationship, there is the need to capitalize on the emerging paradigm shift. Indeed, emphasis should be on preventing these vices by solving problems that give birth to them. All over the Shari'ah states, there are urgent needs to ameliorate cases of unemployment, poverty, illiteracy and the theft of public resources by government officials and their agents. Shari'ah compliant governments should frontally confront illiteracy, the artificial incidence of social division and gaps leading to friction; the preponderance of incongruent values and nauseating tendencies leading to exploitative traits on women-folk and indeed the distorted approach to religio-traditional scholarship under Almajiranci.

It is a Shari'ah requirement that an appropriate integrative framework to fending for the poor, the destitute, the aged, the women, the children and other less privileged groups in the face of the crushing and harsh economic policy of liberalization be worked out, instituted and implemented. These are the serious challenges to the Shari'ah States of Nigeria.

\section{Conclusion}

The larger part of Nigerian areas experienced the full application of Shari'ah before the advent of the British Colonial rule from the late $19^{\text {th }}$ Century. The British meticulously eroded the application of the law in its over six decades of administration in Nigeria. The return of democracy to political governance in Nigeria from 1999 rekindled the fervor and agitation for the Islamic legal system using the framework of the operational 1999 constitution. However the application of the law so far in most parts of Northern Nigeria show leaves much to be desired. It is discriminatively 
applied while the good governance side of the system is not felt by the people. Injustice, illiteracy, destitution, child hawking, street begging and wide socio material gap still pervade the urban and rural centers of the Shari'ah states. If Shari'ah application in these states is to be meaningful as obviously desired by the people, it has to be applied in such a way that it check official corruption, general poverty and gender inequity. It should foster good governance, accountability, improved material well beings and provide capital for investment through the existing Islamic micro windows. In addition, Shari'ah application needs to be methodological with recognized phases.

\section{References}

Abubakar, S. (1999). The Northern Provinces under Colonial Rule: 1900-1959. In O. Ikime (Ed). Groundwork of Nigerian History, (pp.447-481). Ibadan, Nigeria: Heinemann Educational Books, Plc.

Adesubokun V Yunusa. (1971) 1 All Nigerian Law Report, p 226

Badamasiuy B. J. (2011). Constitutionalism and Representative Government. In H. Salihi; B.A. Umar \& H. A Suleiman (Eds). Shari'ah, Democracy and Good Governance in Islam, (pp 76 - 102). Kano, Nigeria: Bayero University \& IIIT (Kano Office).

Bako S. (2002). The Crisis of Transition to Democracy under Obasanjo Presidency. In A. M. Jega ; H. Wakili and M. Ahmad (Eds). Democracy and Democratization in Nigeria 1999-200,(pp.1 - 15). Kano: CDRT, B.U.K.

Constitution of the Federal Republic of Nigeria. (1979).

Constitution of the Federal Republic of Nigeria. (1999).

Daily Sun March $23^{\text {rd }}$. (2005).

Great Britain, Colonial office (GBCO) (1945). Proposals for the Revision of the Constitution of Nigeria, Cmd 6599, London HMSO.

High Court Law (cap 49 Northern Nigeria Laws 1963

Johnson, P. and Lee, C. (2003). Political Liberalization and Democratic Change in Sub-Saharan Africa, 1970-1995: A Cross Section Analysis. Democracy and Development Journal of West African Affairs, Harmattan Edition Vol. 3 No.2., (pp.7-15).

Joseph, R (2003). State, Governance and Insecurity in Africa. Democracy and Development Journal of West African Affairs, Harmattan Edition Vol. 3 No.2., (pp. 39 -51 ).

Kumo S. (1986). The Application of Islamic Law in Northern Nigeria: Problems and Prospects. In K.R. Syed (Ed). Islamic Law in Nigeria, (pp.42-51). Lagos: Islamic Publication Bureau.

Kurawa I. A. (2000). Shariah and the Press in Nigeria; Islam Versus Western Civilization. Kano, Nigeria: Kurawa Holdings, (Chapter 5).

Ladan, M.T. (2003). Women's Right, Access to and Administration of Justice Under Shari'ah in Nigeria. In J. N. Ezeilo; M.T. Ladan and A. Afolabi-Akiyode, (Eds). Shari'ah Implementation in Nigeria: Issues and challenges in Women's Rights and Access to Justice, (pp.19 - 43). Lagos, Nigeria: WACOL \& WARDC.

Mahmud A. B. (1988) A Brief History of Shari'ah in the Defunct Northern Nigeria, Jos: University of Jos Press, (Chapter 3).

Maududi S. A. A. (1975). The Islamic Law and Constitution. Lahore, Pakistan: Islamic Publication Ltd, (Chapters 1).

Muazam, I. (2002). Islam in a Plural Society: Between Sacred and Profane. In E.E.O. Alemika \& F.Okoye, (Eds). Ethno-Religious Conflicts and Democracy in Nigeria: Challenges, (pp. 185-119). Kaduna, Nigeria: Human Rights Monitor.

News Papers and Magazines:

O'Donnell, C. and Schmitter, P.C (1986). Transitions from Authoritarian Rule, Tentative Conclusions about Uncertain Democracies. London: John Hopkins University press, (Chapter 1).

Okene, A. A \& Shukri, A. (2011). Ibn Khaldun, Cyclical Theory and The Rise and Fall of Sokoto Caliphate, Nigeria West Africa. In International Journal of Business and Social Sciences, Vol. 2. No. 4. CPI, USA, (pp. 80-91).

Okene, Ahmed A. (2005). Stemming Ethno-Religious Conflict in Nigeria, The role of Good Governance and Democratic Consolidation. In A. M. Yakubu, R.T. Adegboye, C.N. Ubah and B. Dogo (Eds). Crises and Conflict Management in Nigeria Since 1980, (pp. 818 -836). Kaduna, Nigeria : Baraka Press and Publishers Ltd.

Proclamation No 51900 
Siddique F. R. (2009). The Concept of Islamic State from the Time of the Four Caliphates Till the $20^{\text {th }}$ Century; Post-ikhwan and Pre-Ikhwan. Lebanon: Kotob Al-Ilimiya, (Chapter 3).

Smith, A. (1987). A Little Light Vol.1: A Collection of the Writings of Abdullah Smith. Zaria, Nigeria : Centre for Historical Research and Documentation.

Suleiman, I. (1986). A Revolution in History The Jihad of Usman Danfodio. London: Mansell Publication ltd, (Chapter 2).

Tabiu, M. (1986). Constraints in the Application of Islamic Law in Nigeria. In K. R. Syed (Ed). Islamic Law in Nigeria, (pp. 75 - 85). Lagos, Nigeria: Islamic Publication Bureau.

Tell Magazine November 15, 1999

The Post Express $13^{\text {th }}$ April 2001

Weekly Trust November 12, 1999

Yadudu, A. H (1991). Colonialism and Transformation of the Substance, Methodology and Application of Islamic Law in Nigeria (pp.1 - 15). In Journal of Law and Religion, Vol. IX.

Yadudu, A.H. (2003). Dialogue of the Deaf": The Shari'ah Debate in Nigeria. In Zakariyau Husseini (Ed). A Digest of Islamic Law and Jurisprudence in Nigeria, (pp.1 - 5 ). Auchi, Nigeria: Darun- Nur \& Abuja, NAMLAS. 